\title{
Construction of Classroom Practice Teaching mode of Applied Undergraduate English Specialty
}

\author{
Guobo Jiang \\ Foreign Language Department, Ankang University, Ankang 725000, China
}

Keywords: Applied university; English specialty; Classroom practice teaching mode; Construction

\begin{abstract}
Creation of classroom practice teaching mode for undergraduate English specialty is an important teaching content in English practice teaching system construction. So, it is required to reform and innovate applied undergraduate English in practical teaching process and then meet teaching needs of English teaching and students' training objective. This paper analyzes current situation of classroom practice teaching mode of English specialty in detail, and puts forward corresponding solutions in allusion to problems and shortcomings of classroom practice teaching so as to effectively promote learning and comprehensive ability of students majoring in English.
\end{abstract}

\section{Introduction}

Classroom practice teaching mode of applied undergraduate English specialty innovates and reforms English classroom teaching mode of universities. Applied universities are dominated by specialty knowledge cultivation in the process of cultivating students in order to effectively give play to specialty advantages after their graduation. In actual teaching process, classroom practice teaching is dominated to effectively motivate students' specialty learning passion and interest, attract students to take active part in classroom practice teaching activity and then promote students' learning effect and quality. In classroom practice teaching of applied university English specialty, active construction of practice teaching mode suitable for students has certain practical significance.

\section{Status analysis of classroom practice teaching of undergraduate English specialty}

To respond to modern education system reform, in terms of cultivating applied university talents, practice teaching mode of undergraduate English specialty has been reformed and innovated, especially in classroom practice teaching. But, certain defects and shortcomings still exist in classroom practice teaching process of applied undergraduate English specialty. The teaching concept is fuzzy, and actual practice teaching system falls behind. Thus, students' psychological needs cannot be met. Students' attention cannot be attracted. In classroom practice teaching process, teaching atmosphere is depressed and dull. This greatly reduces students' passion for and interest in classroom practice activity so that students gradually lose learning interest. Thus, teaching objective of undergraduate English specialty cannot be effectively achieved. Therefore, construction of classroom practice teaching mode of undergraduate English specialty which complies with social needs is a key content of applied universities in current stage. Applied English talents continuously require corresponding reform and innovation of classroom practice teaching mode of undergraduate English specialty in terms of specialized knowledge, professional ability and their comprehensive quality, constructing unique practice teaching mode and achieving personnel training objective.

In a bid to give full play to characteristics of applied universities, it is required to innovate teaching ideas, abandon classroom teaching system which does not comply with modern teaching and carry out active adjustment in combination of actual social needs. Education characteristics of applied universities are as follows: it own very strong practicability, pays attention to training students' professional skills, while classroom practice teaching is the best form which effectively promotes the above objective of personnel cultivation. So, in actual teaching work, it is required to correctly cognize essential differences between classroom practice teaching mode and traditional teaching mode. The importance of practice classroom teaching manifests significance as modern education 
system continuously goes deep. Most applied universities input much manpower, many material resources and financial resources in practice teaching, perfect software and hardware facilities of universities and mainly focus on English talent cultivation.

\section{Specific implementation strategies of constructing classroom practice teaching mode of undergraduate English specialty}

\section{To effectively specify teaching objective of classroom practice teaching of undergraduate English specialty}

In allusion to classroom practice teaching of applied undergraduate English specialty, it is required to regard cultivation of students' comprehensive English application ability as the main starting point, correctly understand English talent training objective, specify actual purpose of classroom practice teaching, focus on training actual communicative competence and language application ability training, activate learning atmosphere of English classroom in combination of corresponding English classroom practice activities, effectively facilitate students' learning initiative and boost professional learning efficiency. In teaching process of English language foundation, it is required to actively combine pictures, voice frequency and videos related to teaching contents and innovate classroom teaching modes and methods. In addition, teachers may organize corresponding classroom practice teaching activities, prepare relevant English dialogues according to classroom contents and then improve students' interest in learning English foundation knowledge. Besides, this is beneficial to improving students' communication ability and learning ability. Meanwhile, learning objectives of English specialty and learning tasks are combined with actual English communicative competence, which to some extent activates classroom teaching atmosphere, establishes harmonious relations between students and English teachers, achieves classroom teaching interaction and effectively completes classroom teaching objective. Furthermore, in classroom practice teaching process of English specialty, simulation of dialogues in classroom helps students establish correct specialized knowledge learning attitude to some extent.

\section{Rational design of classroom practice teaching course system of English specialty}

In allusion to design problem of classroom practice teaching course system of English specialty, students' future employment should be fully considered. In the aspect of course design, it is required to mainly cultivate students' English comprehensive applications ability. In English classroom practice teaching process, it is required to plan and formulate classroom teaching practice activity in combination of actual jobs so that students can solve learning problems in inquiry learning process and gain certain learning experience. Students acquire real experience of English classroom practice teaching through personal experience, communication with enterprises or units and exchange with English knowledge so as to promote their interest in and enthusiasm for English learning. Rational design of classroom practice teaching course system of applied undergraduate English specialty can effectively drive realization of English talent training objective. In allusion to talent training objective of applied undergraduate English specialty, it is necessary to requirements of knowledge, ability and comprehensive quality in detail, combine knowledge structure of English specialty and actual demand for talents by market in a scientific and rational way, reform and innovate original English course idea and course design to achieve classroom practice teaching mode of English specialty.

Design thought of classroom practice teaching system of university English specialty

The design of English classroom practice teaching system should manifest its comprehensiveness, not just including practice of English pubic courses and specialized courses, but also containing teaching system design of classroom practice and extracurricular practice. In addition, course system design of university English specialty should take into account of expertise, be closely related to actual conditions of university English specialty and lay emphasis on training the ability of English listening, speaking, reading and writing. It is required to pay attention to the importance of classroom practice teaching while cultivating professional skills of students majoring English. Meanwhile, in classroom practice teaching course system construction, it should be rationally allocated to different 
semesters and students; credits to effectively drive in-depth implementation of English classroom practice teaching mode.

\section{Content module of English classroom practice teaching mode}

Practice teaching system of university English specialty consists of classroom practice and extracurricular practice. Classroom practice teaching system includes practical activities listed in English talent training system, such as English course with practice nature, disperse practice and concentrated practice. Extracurricular practice refers to the practice which is not listed in English talent training system, but extracurricular practice plays certain promotion role in training comprehensive abilities of students’ English learning.

Practice-based English courses of English specialty mainly include spoken language, writing and translation knowledge. All English practice courses need to be studied in combination of theory and practice.

Disperse practice is listed in English talent training objective and planning. Although it is included in part credits, corresponding English study arrangement is not conducted. Hence, disperse practice is flexible. Different universities may carry out different setting in English teaching process. With training students' English reading ability and increasing reserve of English knowledge as major objectives, disperse practice study form may be transformed to requirements for students' daily learning form. Corresponding reading tasks may be allocated to students, and regular examination may be conducted. Such learning form transformation is a special expression form of disperse practice study. Such disperse practice study from can improve teachers' management of students.

Concentrate practice mainly involves students' military training, graduation practice and paper practice. Besides, these traditional practice teaching items are indispensible links in campus life. Correct management and implementation should be conducted. However, during designing classroom teaching course system, design space is large relative to concentrated practice. For professional practice design of university English specialty, it can be divided into diverse English learning practice modules. In diverse English learning stages, different English practical activities may be designed. Firstly, students may be trained for relevant posts in the first semester, which can also enhance students' professional skills and knowledge. To better train students for professional English knowledge and related posts, English teachers may invite related successful English people to give lectures or lead students to visit and know English enterprises. In the second semester, basic teaching of English specialty draws to a close, so English teachers may carry out concentrated training for students' professional ability. In allusion to promotion of oral English competence, teachers may organize oral English competitions and program performance so that students can train oral English competence in practice process and facilitate their enthusiasm for English study. When teachers train students' English skills, they should grasp the degree and avoid blind strict training, or else students will gradually lose English learning interest. In the third semester, teachers should implement targeted concentrated practice training and design practice training system according to students' specialty direction. Any specialty direction must accord with actual conditions of English specialty and students' actual learning conditions. Teachers should rationally assess training process and then ensure implementation quality of practice teaching of English specialty.

English extracurricular practice teaching has certain promotion function for cultivating students' English level and skills. Teachers should positively encourage students to participate in different English activities in their spare time. Students may organize English corner autonomously and invite senior students with high English skills or teachers to analyze relevant knowledge and exchange English information. These English extracurricular practical activities can effectively boost students' English learning interest and enthusiasm, their self-development ability and thinking creation, and effectively shape their comprehensive English abilities. Students' positive performance in extracurricular practical English teaching fully reflects their knowledge application ability in English classroom teaching. 


\section{Construction of practice course of classroom practice teaching mode of university English}

After overall design of classroom practice teaching system of applied university English specialty, scientific and reasonable implementation should be carried out. In terms of English talent cultivation, practice teaching of English course should gradually go deep into different learning semesters. Classroom practice teaching and extracurricular practice teaching with certain system nature will be combined to finally construct an all-around classroom practice teaching system of English specialty to drive learning process and cultivate high-quality inter-disciplinary English talents.

\section{Conclusions}

Effective construction of applied classroom practice teaching mode is a long-term and complex process, especially for English specialty. Talent training objective of English specialty is mainly dominated by basic knowledge of English, while English study is a discipline with strong practicalness. Effective reinforcement of English practice teaching to some extent improves students' English language level. This paper analyzes current situation of classroom practice teaching mode of English specialty in detail and finds out defects and problems. However, since different universities have different school-running modes and methods in English teaching work and teaching directions also have certain differences. Therefore, there are differences in classroom practice teaching. Systematic design of classroom practice teaching mode of university English specialty is a reference model of classroom practice teaching mode design of English specialty. Specific classroom practice teaching mode should be designed according to teaching conditions of English specialty so as to perfect teaching method of classroom practice teaching, facilitate students’ English study enthusiasm and boost students’ English learning level.

\section{References}

[1] Yu Aihua, Exploration of applied university English acuity course. Fast Reading (the last ten-day of a month), 2014(10)

[2] Yin Hong, Exploration of paths to transform college English to applied teaching. Youthful Days, 2012(14)

[3] Cao Liang, Strategies to train students' autonomous learning ability under applied college English teaching mode. Economic \& Trade Update, 2014(1)

[4] Dai Rui, Tao Xianglong, Classroom practice teaching of applied universality English major. Journal of Jiamusi Education Institute, 2012(8)

[5] Xia Caiyun, Exploration of improving effectiveness of English classroom "applied activity teaching”. Science Times, 2012(9) 